\title{
OPEN Heavy metal contamination in Peru: implications on children's health
}

\author{
Xulia Fandiño Piñeiro', Mauro T. Ave ${ }^{1,2,3,4,5}$, Narmeen Mallah ${ }^{5,6,7 凶}$, \\ Francisco Caamaño-Isorna ${ }^{5,6,7}$, A. Nuria Guisández Jiménez ${ }^{1}$, Duarte Nuno Vieira ${ }^{8}$, \\ Flaviano Bianchini ${ }^{9}$ \& José Ignacio Muñoz-Barús ${ }^{1,2}$
}

Cerro de Pasco, Peru, has been excessively contaminated with heavy metals due to high mining activities in the region. We investigated the presence of chronic exposure to heavy metals in children living in Cerro de Pasco and its effect on health. Heavy metal concentrations were determined in hair samples collected from 78 children living in a region exposed to an open-pit mine (Paragsha region) and from other 16 children unexposed to mine activities (Carhuamayo region). Children exposed to the mine showed statistically significant higher concentration of aluminum, antimony, arsenic, cadmium, chromium, iron, lead, tin and thallium $(p<0.05)$ than control children. Hair samples collected from the same children in two occasions (2016 and 2018) showed that the exposure is chronic with higher levels of heavy metals observed in 2018. The concentration of heavy metals was higher in hair tip than in hair root samples. Heavy metals are associated with substantial higher risk of nosebleed (odds ratio, $O R=15.40)$, chronic colic $(O R=7.30)$, dermatologic alterations $(O R=6.16)$, mood alterations $(O R=7.07)$, presence of white lines on nails $(O R=12.10)$, reduced visual camp $(O R=3.97)$ and other symptoms (OR = 5.12). Chronic heavy metal exposure implies various negative consequences on children's health. Preventive measures are crucial to protect children's health.

Heavy metals is a widely used term to refer to a category of metallic elements of high molecular weight $(\geq 20)$ and density when compared to water $\left(\geq 5 \mathrm{~g} / \mathrm{cm}^{3}\right)^{1,2}$. Heavy metals are naturally occurring, and their presence at very low levels is essential to maintain various biochemical and physiological functions in living organisms ${ }^{3}$.

Human activities such as mining contribute to increasing the release of heavy metals into the environment ${ }^{4}$. Contamination caused by mining activities is associated with huge environmental burdens, and is considered as a situation of environmental crime by many experts. Environmental crimes are characterized by their impact on the nature, increasing the levels of pollution, degrading the wildlife, reducing the biodiversity, disturbing the ecological balance and causing irreversible climate change ${ }^{5}$. Several analytical methods to detect heavy metals in food chain and environment and to eliminate those metals when present in high concentrations have been published elsewhere ${ }^{6-10}$.

Exposure to high levels of heavy metals is also associated with health consequences, though their toxic effects vary according to the forms and routes of exposure ${ }^{11}$. Heavy metals usually interrupt intracellular homeostasis through the production of free radicals which interact with other chemicals and biological molecules and consequently lead to lipid, protein and DNA damage ${ }^{11}$. For instance, arsenic, a highly toxic heavy metal, stimulates the production of arsenic induced superoxide which plays a main role in disrupting various cell signalling pathways through the interaction with biological macromolecules, leading to DNA damage, lipid peroxidation and alteration of antioxidant enzyme levels ${ }^{12}$. Consequently, heavy metals exposure contributes to the development

\footnotetext{
${ }^{1}$ Department of Forensic Sciences, Pathology, Gynecology and Obstetrics, Pediatrics, University of Santiago de Compostela, Santiago de Compostela, Spain. ${ }^{2}$ Institute of Forensic Sciences, University of Santiago de Compostela, Santiago de Compostela, Spain. ${ }^{3}$ Complejo Hospitalario Universitario de Santiago de Compostela, Santiago de Compostela, Spain. ${ }^{4}$ Centro de Investigación Biomédica en Red de Enfermedades Cardiovasculares (CIBERCV), Madrid, Spain. ${ }^{5}$ Instituto de Investigación Sanitaria de Santiago (IDIS), Santiago de Compostela, Spain. ${ }^{6}$ Department of Preventive Medicine, University of Santiago de Compostela, R/San Francisco, $s / n$, 15782 Santiago de Compostela, Spain. ${ }^{7}$ Centro de Investigación Biomédica en Red de Epidemiología y Salud Pública (CIBERESP), 28029 Madrid, Spain. ${ }^{8}$ Department of Legal Medicine and Ethical Sciences, Faculty of Medicine, University of Coimbra, Coimbra, Portugal. ${ }^{9}$ Source International, Calci, Pisa, Italy. ${ }^{\square}$ email: narmeen.mallah@usc.es
} 
of major diseases such as cancer and respiratory, neurological, and kidney diseases, and eventually drives to death $^{1,3,13-16}$.

In Peru, the mining sector has been continuously expanding with the mining activities concentrated in the central and southern regions of the country ${ }^{17}$. Peru ranks among the top five producers of heavy metals like copper, lead and zinc ${ }^{18}$. The City of Cerro de Pasco, located at the top of Peruvian Andes, is a mining town and considered one of the most contaminated places on earth ${ }^{19}$. The mining activity in the Peruvian Andes takes place on farmers community lands and headwaters ${ }^{20}$, and the presence of excessive levels of heavy metals in the air, soil (agricultural and recreational) and water has been already demonstrated ${ }^{20-25}$. More than one and a half million people in Peru are exposed to lead in soil ${ }^{26}$. The Peruvian government has recently placed a barrier surrounding the mine to reduce heavy metal pollution.

A recent report has pointed out the devastating impact of heavy metal contamination due to metallurgical emissions on health in Cerro de Pasco ${ }^{27}$. Previous studies also reported alarming figures such as the presence of blood-lead levels higher than $10 \mu \mathrm{g} / \mathrm{dL}$ in children living in this district ${ }^{21,23-25}$. Lead is classified as carcinogenic and is the second most harmful heavy metal after arsenic ${ }^{28}$. Though such disturbing findings have been reported since $1996^{29}$, the health consequences of heavy metal pollution in Peru have not been sufficiently investigated, standards to regulate the heavy metal content such as lead in the soil are still unavailable ${ }^{26}$, and regulations to control mining activities are weak.

Accordingly, we aimed in the present study to determine the health effects of exposure to heavy metals in a children population in Cerro de Pasco (Peru), and to investigate if the barrier placed around the mine reduces the exposure to heavy metals. We also explored the association of chronic pollution with certain health conditions and examined the effect of exposure to multiple heavy metals on body organs and systems.

\section{Materials and methods}

Settings and population. Cerro de Pasco is the capital of the province of Pasco, located in the Central Zone of Perú and has a population size of around 80,000 inhabitants. An open pit mine is located in the same capital, and the mining activities generates air, water and soil contamination ${ }^{21,23}$.

The study population consisted of children between 3 and 16 years of age who had a permanent residence in the study area: Paragsha zone in Cerro de Pasco and Carhuamayo city. The open-air mine hole is situated at approximately $400 \mathrm{~m}$ from Paragsha zone, i.e., Paragsha is directly exposed to the activities carried out in the mine. Carhuamayo is located at $35 \mathrm{~km}$ from Cerro de Pasco in a southeast direction but shares similar sociogeographic and atmospheric characteristics to those of Paragsha.

Ethics. The participation in the study was voluntary. Parents of participating children provided a signed informed consent before their recruitment. The study was approved by the ethics committee of the University of Santiago de Compostela (Protocol No. 08102019) and was carried out in compliance with the corresponding legal and ethical requirements (Spanish Acts 14/2007 and 3/2018).

Sample. In 2018, hair samples were collected from 94 children. Hair was the type of chosen samples to measure heavy metal concentration because it allows determining if the children have been chronically exposed to these metals, and at the same time it is also a non-invasive and stable method ${ }^{30}$. Due to the lack of standards that specify the "normal" and the "toxic" levels of heavy metals in hair, and in line with previous studies, we adopted the reference values for children that were established by the Micro Trace Minerals (ER) laboratory (Table 1) ${ }^{23}$.

Seventy-eight children were recruited from Paragsha; the region exposed to heavy metals. Twenty-seven of the 78 exposed children were included in a previous study that was undertaken in $2016^{23}$, hence data from two periods are available for those children. Sixteen other children were recruited from Carhuamayo and served as the group unexposed to heavy metals.

Anamnesis and examination. All recruited children underwent a complete physical examination and anamnesis. In the anamnesis, we inquired about respiratory, digestive, bleeding and neurological antecedents, among others. In addition, data were collected on vaccine administration, medical and hospitalization history and the reasons for medical assistance or interventions, when applicable.

In the clinical examination, we assessed many ophthalmoscopic and otoscopic aspects such as: children's development and general condition, as well as abdominal, respiratory, dermatological, ophthalmological, cardiovascular, digestive, auditory, urinary and neurological complaints. Regarding the external examination, information was collected on the presence/absence of skin with an earthy color, breath and acid sweat, bleeding, fever at the time of the evaluation, among others. The presence of specific features potentially related to exposure to heavy metals was investigated, such as: Café-au-lait spots (coffee-with-milk-colored spots) in various parts of the children's body, deafness, inflamed conjunctiva, bluish lines on the edge of the gums, constipation, diarrhea, cramps and white lines on the nails or Mees lines.

At the end of the examination, hair samples were collected from the nape of the neck.

Laboratory analysis. All the collected hair samples were processed, using $1 \mathrm{~cm}$ fragments, and analyzed, in a certified laboratory, by Inductively Coupled Plasma Mass Spectrometry, ICP-MS, following previously published procedures ${ }^{31}$. The concentration of 21 heavy metals was determined: aluminium (Al), antimony (Sb), arsenic (As), boron (B), barium (Ba), beryllium (Be), cadmium (Cd), cobalt (Co), chromium (Cr), iron (Fe), magnesium $(\mathrm{Mn})$, mercury $(\mathrm{Hg})$, molybdenum $(\mathrm{Mb})$, nickel $(\mathrm{Ni})$, lead $(\mathrm{Pb})$, copper $(\mathrm{Cu})$, selenium $(\mathrm{Se})$, tin $(\mathrm{Sn})$, thallium $(\mathrm{Tl})$, vanadium $(\mathrm{V})$ and zinc $(\mathrm{Zn})$. 


\begin{tabular}{|l|l|c|c|c|c|}
\hline \multirow{2}{*}{ Metal (mg/kg) } & \multirow{2}{*}{$\begin{array}{l}\text { Exposed group } \\
\text { (Paragsha) }\end{array}$} & \multicolumn{2}{l|}{$\begin{array}{l}\text { Unexposed group } \\
\text { (Carhuamayo) }\end{array}$} \\
\cline { 3 - 6 } & Reference value & Hair root & Hair tip & Hair root & Hair tip \\
\hline $\mathrm{Al}$ & $<8.00$ & 30.22 & 47.30 & 22.31 & 26.90 \\
\hline $\mathrm{Sb}$ & $<0.20$ & 0.12 & 0.24 & 0.05 & 0.14 \\
\hline $\mathrm{As}$ & $<0.20$ & 0.47 & 0.42 & 0.18 & 0.14 \\
\hline $\mathrm{Ba}$ & $<2.65$ & 1.18 & 4.98 & 0.86 & 3.72 \\
\hline $\mathrm{Be}$ & $<0.03$ & 0.002 & 0.005 & 0.001 & 0.003 \\
\hline $\mathrm{B}$ & $<0.84$ & 2.64 & 2.70 & 1.72 & 2.19 \\
\hline $\mathrm{Cd}$ & $<0.20$ & 0.10 & 0.40 & 0.04 & 0.13 \\
\hline $\mathrm{Co}$ & $<0.15$ & 0.04 & 0.17 & 0.02 & 0.074 \\
\hline $\mathrm{Cr}$ & $0.02-0.15$ & 0.83 & 1.61 & 0.39 & 0.88 \\
\hline $\mathrm{Fe}$ & $7.70-15.00$ & 55.11 & 68.36 & 29.82 & 42.30 \\
\hline $\mathrm{Mn}$ & $0.07-0.50$ & 5.22 & 13.41 & 2.15 & 4.74 \\
\hline $\mathrm{Hg}$ & $<0.30$ & 0.24 & 0.41 & 0.34 & 0.31 \\
\hline $\mathrm{Mo}$ & $0.02-1.00$ & 0.24 & 0.20 & 0.80 & 0.09 \\
\hline $\mathrm{Ni}$ & $<0.85$ & 1.96 & 9.78 & 2.96 & 14.11 \\
\hline $\mathrm{Pb}$ & $<0.10$ & 4.58 & 10.37 & 0.81 & 2.69 \\
\hline $\mathrm{Cu}$ & $6.70-37.00$ & 13.49 & 27.27 & 10.46 & 17.60 \\
\hline $\mathrm{Se}$ & $0.40-1.70$ & 8.73 & 1.26 & 0.79 & 0.71 \\
\hline $\mathrm{Sn}$ & 0.93 & 42.0 & 79.16 & 0.11 & 0.55 \\
\hline $\mathrm{Tl}$ & $<0.01$ & 0.02 & 0.02 & 0.01 & 0.005 \\
\hline $\mathrm{V}$ & $0.01-0.15$ & 0.06 & 0.20 & 0.04 & 0.08 \\
\hline $\mathrm{Zn}$ & $110.0-227.0$ & 200.71 & 488.79 & 188.81 & 258.00 \\
\hline
\end{tabular}

Table 1. Average concentrations of heavy metals measured in hair roots and hair tip samples collected in 2018 from children exposed and unexposed to the mine. ${ }^{\text {a }}$ Reference values for children used by Micro Trace Minerals Laboratory in Germany. Hair tip samples were collected at $20 \mathrm{~cm}$ from the hair root. Al aluminium, As arsenic, $B$ boron, $B a$ barium, $B e$ beryllium, $C d$ cadmium, Co cobalt, $C r$ chromium, $F e$ iron, $M n$ magnesium, $\mathrm{Hg}$ mercury, $\mathrm{Mo}$ molybdenum, $\mathrm{Ni}$ nickel, $\mathrm{Pb}$ lead, $\mathrm{Cu}$ copper, $\mathrm{Sb}$ antimony, Se selenium, $\mathrm{Sn}$ tin, $\mathrm{Tl}$ thallium, $\mathrm{V}$ vanadium, $Z n$ zinc.

The analytical procedure consisted of the following steps: (1) cutting the hair samples into parts of about $1 \mathrm{~cm},(2)$ immersion of the hair samples in a mixture of acetone/ethyl ether ( $1+4 \mathrm{v} / \mathrm{v})$ for $30 \mathrm{~min}$, (3) drying in a stove at a maximum of $40{ }^{\circ} \mathrm{C}$, (4) second immersion in $5 \%$ ethylenediaminetetraacetic acid (EDTA) solution for $30 \mathrm{~min}$, (5) rinsing with de-ionized water, (6) drying in a stove at a maximum of $40^{\circ} \mathrm{C}$, (7) after the washing phase, each sample was weighed (about $0.1000-0.4000 \mathrm{~g}$ ) and subsequently mineralized in a microwave device in high-pressure Teflon vessels, with a mixture of nitric acid and hydrogen peroxide in proportion $5+1(\mathrm{v} / \mathrm{v})$. The thermal program consisted of two steps. In the first step, the samples were incubated at $90{ }^{\circ} \mathrm{C}$ for $3 \mathrm{~min}$. In the second step, the samples were placed at $120^{\circ} \mathrm{C}$ for $5 \mathrm{~min}$. Subsequently, the samples were cooled down for $30 \mathrm{~min}$. A blank control and a reference material were also mineralized with each sequence of samples. The solution was transferred into a volumetric flask and analyzed by ICP-MS technique.

Results were sub-grouped in order to compare the part of the hair that has been exposed to metals the longest (hair tip, at a $20 \mathrm{~cm}$ from the hair root) to the part of the hair that has been exposed for the least duration (hair root). Assuming that the rate of hair growth is $0.6-1.4 \mathrm{~cm} /$ month, a hair tip located at $20 \mathrm{~cm}$ from the root, would be equivalent to an exposure duration of 12 to 28 months before sample collection ${ }^{32}$.

Statistical analysis. Chronic exposure to heavy metals. To determine the presence of chronic exposure to heavy metals, we calculated the mean difference of heavy metal concentration between hair root samples of the same individuals collected in 2016 and 2018 and tested the statistical significance of this difference using T-student test.

T-student test for paired samples was also undertaken to compare heavy metal concentrations in hair tip samples collected in 2018 with that of hair root of the same individuals (Table S2 of supplementary materials).

Association of heavy metals with clinical symptoms. We investigated the associations of heavy metal concentrations, irrespective of the place of residence, with the manifestation of clinical symptoms (nosebleed, white line on nails and chronic colic) by calculating Pearson's chi-squared $\mathrm{X}^{2}$ test $\mathrm{p}$-value. We also estimated $\mathrm{X}^{2} \mathrm{P}$-value of linear association to explore if association between heavy metals and clinical symptoms follows a linear trend. For the purpose of these analyses, children were sub-grouped into terciles of the concentration of heavy metals detected in their hair: low, medium, and high.

To verify if the manifestation of nosebleed and the presence of white lines on nails is related to exposure to heavy metals, data from a mixed population composed of exposed and unexposed children to the mine were compared using T-student test for independent samples (see supplementary material online, Table S3). 
Association of the place of residence with heavy metal concentration and clinical manifestation. The association of heavy metal concentration with the place of residence (Carhuamayo versus Paragsha) was examined using T-student test. The association of the place of residence with the presence of clinical symptoms was determined by estimating the odds ratio (OR) using logistic regression models.

Analyses were carried out using SPSS (SPSS Inc. Released 2011. SPSS for Windows, Version 20.0. Chicago.

\section{Results}

Participants' general characteristics. Seventy-eight exposed and 16 unexposed children to the mine participated in the study. The gender ratio of the exposed children was 1:1 (39 boys and 39 girls). Three-quarters of the unexposed population were females $(\mathrm{N}=12)$. Both groups, exposed and unexposed, were similar in terms of age (exposed children: average $=10.01$ years; range: $3-16$ and unexposed children: average $=10$ years; range: $5-15$ ), weight (exposed children: average $=31.60 \mathrm{~kg}$; range: $9-60$ and unexposed children: average $=31.16 \mathrm{~kg}$; range: $17-46$ ), height (exposed children: average $=132.68 \mathrm{~cm}$; range: $95-164$ and unexposed children: average $=134.62 \mathrm{~cm}$; range: $111-152$ ), body temperature (exposed children: average $=35.93{ }^{\circ} \mathrm{C}$; range: $34.10-37.70$ and unexposed children: average $=35.53{ }^{\circ} \mathrm{C}$; range: $33.4-36.0^{\circ} \mathrm{C}$ ), systolic blood pressure (exposed children: average $=86.28 \mathrm{mmHg}$; range: $70-120$ and unexposed children: average $=82.13 \mathrm{mmHg}$; range: $65-105 \mathrm{mmHg}$ ), diastolic blood pressure (exposed children: average $=54.68 \mathrm{mmHg}$; range: $38-85 \mathrm{mmHg}$ and unexposed children: average $=51.88 \mathrm{mmHg}$; range: $38-70 \mathrm{mmHg}$ ), and pulse rate [exposed children: average $=76.90$ pulse per minute (ppm); range: $48-108$ and unexposed children: average $=79.29$ ppm; range: $64-108]$.

In the population exposed to the mine (Paragsha region), the average concentration of heavy metals significantly differed between male and female children (see supplementary material online, Table S1). Due to the limited number of male children in the non-exposed population, gender differences with regards to heavy metals concentration were not explored.

Presence of heavy metals in hair root and hair tip. Table 1 represents the average concentration of heavy metals measured in hair root and hair tip (at $20 \mathrm{~cm}$ from hair root samples) samples collected in 2018 from children living in Paragsha (exposed group) and Carhuamayo (unexposed group). In reference to ER, children exposed to the mine had high concentrations of $\mathrm{Al}, \mathrm{As}, \mathrm{B}, \mathrm{Cr}, \mathrm{Fe}, \mathrm{Mn}, \mathrm{Ni}, \mathrm{Pb}, \mathrm{Se}, \mathrm{Sn}$ and $\mathrm{Tl}$ in their hair root and of $\mathrm{Al}, \mathrm{Sb}, \mathrm{As}, \mathrm{Ba}, \mathrm{B}, \mathrm{Cd}, \mathrm{Co}, \mathrm{Cr}, \mathrm{Fe}, \mathrm{Mn}, \mathrm{Hg}, \mathrm{Ni}, \mathrm{Pb}, \mathrm{Sn}, \mathrm{Tl}, \mathrm{V}$ and $\mathrm{Zn}$ in their hair tip. Children unexposed to the mine had elevated concentrations of $\mathrm{Al}, \mathrm{B}, \mathrm{Cr}, \mathrm{Fe}, \mathrm{Mn}, \mathrm{Hg}, \mathrm{Ni}$ and $\mathrm{Pb}$ in their hair root as well as in their hair tip (Table 1).

Chronic exposure to heavy metals. The comparison of heavy metal concentrations between hair root samples collected in 2016 and 2018 revealed a chronic exposure. Hair root samples collected in 2018 have statistically significant higher concentrations of $\mathrm{Al}, \mathrm{Sb}, \mathrm{Ba}, \mathrm{Cd}, \mathrm{Co}, \mathrm{Cr}, \mathrm{Fe}, \mathrm{Mn}, \mathrm{Mo}, \mathrm{Ni}, \mathrm{Pb}, \mathrm{Cu}, \mathrm{Se}, \mathrm{Sn}, \mathrm{V}$ and $\mathrm{Zn}$ than that in samples collected in 2016 (Table 2). The largest differences of concentrations were observed for Sn (difference of average concentration between 2018 and $2016=30.98 \mathrm{mg} / \mathrm{Kg}$ ) and $\mathrm{Al}$ (difference of average concentration between 2018 and $2016=10.17 \mathrm{mg} / \mathrm{Kg}$ ). Inversely, the heavy metals B and Be were more abundant in samples collected in 2016 than that of 2018.

The concentration of the tested heavy metals significantly differed between hair tip and hair root in samples collected in 2018 from the same individuals (T-test p-value >0.05) (see supplementary material online, Table S2). Hair tip samples showed higher concentrations of $\mathrm{Al}, \mathrm{Sb}, \mathrm{Ba}, \mathrm{Be}, \mathrm{Cd}, \mathrm{Co}, \mathrm{Cr}, \mathrm{Fe}, \mathrm{Mn}, \mathrm{Mo}, \mathrm{Pb}, \mathrm{Cu}, \mathrm{Sn}, \mathrm{Tl}, \mathrm{V}$ and Zn than hair root samples.

Association of heavy metals with the presence of certain clinical symptoms. A statistically significant association was observed between exposure to heavy metals and the presence of specific clinical signs (T-student for independent samples p-value <0.05) (see supplementary material online, Table S3). We observed statistically significant associations between $\mathrm{Al}, \mathrm{As}, \mathrm{Cd}, \mathrm{Cr}, \mathrm{Fe}, \mathrm{Mn}, \mathrm{Pb}, \mathrm{Sn}$ and $\mathrm{Tl}$ and nose bleeding; between $\mathrm{Al}, \mathrm{Cd}, \mathrm{Fe}, \mathrm{Mn}, \mathrm{Tl}$ and $\mathrm{V}$ and the presence of white lines on the nails; and between As and $\mathrm{B}$ and chronic colic.

Association of heavy metals with clinical manifestations. There is a linear association between high heavy metal concentrations and the presence of specific clinical signs, irrespective of the place of residence (p-value <0.05) (Table 3). In specific, high level of $\mathrm{As}, \mathrm{Cd}, \mathrm{Fe}, \mathrm{Mn}, \mathrm{Pb}$ and $\mathrm{Tl}$ are associated with a history of nosebleed. The heavy metals $\mathrm{Al}, \mathrm{Sb}, \mathrm{As}, \mathrm{Cd}, \mathrm{Co}, \mathrm{Cr}, \mathrm{Fe}, \mathrm{Mn}, \mathrm{Pb}, \mathrm{Sn}, \mathrm{Tl}$ and $\mathrm{V}$ are associated with the presence of white lines on the nails. As and B are associated with chronic colic.

Association of area of residence with heavy metal concentration. There is a statistically significant association between the residence area and the concentration of the following heavy metals: $\mathrm{Al}, \mathrm{Sb}, \mathrm{As}, \mathrm{Cd}$, $\mathrm{Cr}, \mathrm{Fe}, \mathrm{Pb}, \mathrm{Sn}$ and $\mathrm{Tl}$ (Table 4). The concentration of these metals in the hair root of children exposed to the mine is substantially higher than that determined in the hair root of unexposed children. The most notable differences were observed for tin ( $\mathrm{Sn}$ ) [average concentration in Carhuamayo (non-exposed region) $=0.11 \mathrm{mg} / \mathrm{Kg}$ and in Paragsha $($ exposed region $)=42.00 \mathrm{mg} / \mathrm{Kg}$ ] and lead $(\mathrm{Pb})$ [average concentration in Carhuamayo $=0.81 \mathrm{mg} / \mathrm{Kg}$ and in Paragsha $=4.62 \mathrm{mg} / \mathrm{Kg}]$.

Association of area of residence with specific clinical signs. Nosebleed. Half of the children exposed to the mine frequently suffered from nosebleed, while only $6.2 \%$ of the unexposed children reported a 


\begin{tabular}{|c|c|c|c|c|}
\hline \multirow[b]{2}{*}{ Metal } & \multicolumn{2}{|c|}{\begin{tabular}{|l|} 
Concentration \\
$(\mathrm{mg} / \mathrm{kg})$
\end{tabular}} & \multirow[b]{2}{*}{ Mean difference $(\mathrm{mg} / \mathrm{kg})$} & \multirow{2}{*}{$\begin{array}{l}\text { T-test } \\
\text { P-value }\end{array}$} \\
\hline & 2016 & 2018 & & \\
\hline $\mathrm{Al}$ & 18.85 & 29.02 & -10.17 & 0.01 \\
\hline B & 4.48 & 2.08 & 2.40 & $<0.001$ \\
\hline $\mathrm{Ba}$ & 0.56 & 1.09 & -0.53 & $<0.001$ \\
\hline $\mathrm{Be}$ & 0.02 & 0.00 & 0.02 & $<0.001$ \\
\hline $\mathrm{Cd}$ & 0.04 & 0.11 & -0.08 & $<0.001$ \\
\hline Co & 0.02 & 0.04 & -0.03 & 0.016 \\
\hline $\mathrm{Cr}$ & 0.26 & 0.71 & -0.45 & $<0.001$ \\
\hline $\mathrm{Fe}$ & 24.09 & 52.85 & -28.76 & $<0.001$ \\
\hline $\mathrm{Mn}$ & 1.82 & 4.93 & -3.11 & $<0.001$ \\
\hline Mo & 0.06 & 0.08 & -0.03 & 0.002 \\
\hline $\mathrm{Ni}$ & 0.19 & 1.47 & -1.28 & $<0.001$ \\
\hline $\mathrm{Pb}$ & 2.89 & 4.26 & -1.37 & 0.039 \\
\hline $\mathrm{Cu}$ & 7.99 & 11.30 & -3.31 & $<0.001$ \\
\hline $\mathrm{Sb}$ & 0.06 & 0.12 & -0.06 & 0.002 \\
\hline $\mathrm{Se}$ & 0.67 & 0.86 & -0.18 & $<0.001$ \\
\hline $\mathrm{Sn}$ & 0.12 & 31.10 & -30.98 & $<0.001$ \\
\hline $\mathrm{V}$ & 0.03 & 0.05 & -0.02 & $<0.001$ \\
\hline $\mathrm{Zn}$ & 129.11 & 206.85 & -77.74 & $<0.001$ \\
\hline
\end{tabular}

Table 2. Comparison of the mean concentrations of heavy metals detected in hair root samples collected in 2016 and 2018 from the same individuals living in Paragsha. Al aluminium, $B$ boron, $B a$ barium, $B e$ beryllium, $\mathrm{Cd}$ cadmium, Co cobalt, $\mathrm{Cr}$ chromium, $\mathrm{Fe}$ iron, $\mathrm{Mn}$ magnesium, $\mathrm{Mo}$ molybdenum, $\mathrm{Ni}$ nickel, $\mathrm{Pb}$ lead, $\mathrm{Cu}$ copper, $S b$ antimony, $S e$ selenium, $S n$ tin, $V$ vanadium, $Z n$ zinc.

history of nosebleed. The odds of nosebleed are 15 times higher for exposed than that for unexposed children $(\mathrm{OR}=15.45$, p-value $<0.001)$ (Table 5).

White lines on nails. White lines were observed on the nails of more than one-third (34.6\%) of the children exposed to the mine, but they were not seen for any of the unexposed children. The odds of white lines on nails are 12 times higher for exposed than that for unexposed children $(\mathrm{OR}=12.11$, p-value $=0.005)$ (Table 5).

Chronic colic. $\quad 37.2 \%$ of the children exposed to the mine suffered from chronic colic whereas only $6.2 \%$ of the non-exposed children had a history of chronic colic. The odds of chronic colic are seven folds higher for exposed than that for non-exposed children $(\mathrm{OR}=7.30$, $\mathrm{p}$-value $=0.007)($ Table 5).

Dermatologic alterations. dermatologic alterations were detected in almost two-tenth (19.2\%) of the children exposed to the mine but in none of the unexposed children. The observed dermatologic alterations included: café-au-lait spots in flexor areas of the abdomen, back, chest or neck; calluses on palms of the hands; soles with thick and rough skin; and calluses in areas without friction. The odds of dermatologic alterations are five times higher for exposed than that for non-exposed children $(\mathrm{OR}=6.16$, $\mathrm{p}$-value $=0.013)$ (Table 5).

The presence of dermatological alterations significantly differed between male and female children exposed to the mine ( $\mathrm{p}$-value $=0.044$ ). The odds of café-au-lait spots are higher in exposed males than in exposed females $(\mathrm{OR}=4.18 ; \mathrm{p}$-value $=0.041)$.

Other clinical signs. We observed the following clinical signs in the study population: bluish line on the gum, calluses in body areas without friction, calluses on palms and sole with thick and rough skin, and inflamed conjunctiva. Children exposed to the mine have higher odds of developing these clinical signs than unexposed children $(\mathrm{OR}=5.12$, $\mathrm{p}$-value $=0.024)($ Table 5$)$.

Altered mood. more than two-tenth (21.8\%) of the exposed individuals showed an altered mood, i.e., irritability or depression, whereas none of the unexposed children presented these psychological symptoms. The odds of having an altered mood is seven times higher in children exposed to the mine than in unexposed children $(\mathrm{OR}=7.07$, p-value $=0.008)($ Table 5$)$.

\section{Discussion}

We reported the presence of a chronic exposure to heavy metals in children exposed to mine in Cerro de Pasco and detected an association between those metals and several health conditions including history of nosebleed, chronic colic, dermatologic alterations, presence of white lines on nails, constipation, altered mood and reduced visual camp. 


\begin{tabular}{|c|c|c|c|c|c|c|c|c|c|c|c|c|c|}
\hline \multirow[b]{3}{*}{ Metal } & \multirow[b]{3}{*}{ Concentration } & \multicolumn{4}{|l|}{ Nosebleed } & \multicolumn{4}{|c|}{ White lines on nails } & \multicolumn{4}{|c|}{ Chronic colic } \\
\hline & & \multirow[b]{2}{*}{ NoN $(\%)$} & \multirow[b]{2}{*}{ Yes N (\%) } & \multicolumn{2}{|l|}{$\mathrm{X}^{2}$ p-value } & \multirow[b]{2}{*}{ No N (\%) } & \multirow[b]{2}{*}{ Yes N (\%) } & \multicolumn{2}{|l|}{$\mathrm{X}^{2} \mathbf{p}$-value } & \multirow[b]{2}{*}{ No N (\%) } & \multirow[b]{2}{*}{ Yes $\mathrm{N}(\%)$} & \multicolumn{2}{|l|}{$\mathbf{X}^{2} \mathbf{p}^{\text {-value }}$} \\
\hline & & & & linear association & \begin{tabular}{|l|} 
Pearson \\
\end{tabular} & & & \begin{tabular}{|l|} 
linear association \\
\end{tabular} & Pearson & & & Linear association & Pearson \\
\hline \multirow{3}{*}{ As } & Low & $21(67.7)$ & $10(32.3)$ & \multirow{3}{*}{0.001} & \multirow{3}{*}{0.01} & $27(87.1)$ & $4(12.9)$ & \multirow{3}{*}{0.039} & \multirow{3}{*}{0.07} & $26(83.9)$ & $5(16.1)$ & \multirow{3}{*}{0.045} & \multirow{3}{*}{0.1} \\
\hline & Medium & $13(41.9)$ & $18(58.1)$ & & & $20(64.5)$ & $11(35.5)$ & & & $19(61.3)$ & $12(38.7)$ & & \\
\hline & High & $8(26.7)$ & $22(73.3)$ & & & $19(63.3)$ & $11(36.7)$ & & & $18(60.0)$ & $12(40.0)$ & & \\
\hline & Low & $21(67.7)$ & $10(32.3)$ & & & $30(96.8)$ & $1(3.2)$ & & & $23(74.2)$ & $8(25.8)$ & & \\
\hline $\mathrm{Cd}$ & Medium & $14(46.7)$ & $16(53.3)$ & $<0.001$ & $<0.001$ & $18(60.0)$ & $12(40.0)$ & 0.001 & $<0.001$ & $21(70.0)$ & $9(30.0)$ & 0.277 & 0.5 \\
\hline & High & \begin{tabular}{|l|l|}
$722.6)$ \\
\end{tabular} & $24(77.4)$ & & & $18(58.1)$ & $13(41.9)$ & & & $19(61.3)$ & $12(38.7)$ & & \\
\hline & Low & $22(73.3)$ & $8(26.7)$ & & & $27(90.0)$ & $3(10.0)$ & & & $23(76.6)$ & $7(23.3)$ & & \\
\hline $\mathrm{Fe}$ & Medium & $10(32.3)$ & $21(67.7)$ & 0.001 & $\mid<0.001$ & $24(77.4)$ & $7(22.6)$ & $<0.001$ & $\mid<0.001$ & $21(67.7)$ & $10(32.3)$ & 0.199 & 0.4 \\
\hline & High & $10(32.3)$ & $21(67.7)$ & & & $15(48.4)$ & $16(51.6)$ & & & $19(62.3)$ & $12(38.7)$ & & \\
\hline & Low & $21(70.0)$ & $9(30.0)$ & & & $27(90.0)$ & $3(10.0)$ & & & $24(80.0)$ & \begin{tabular}{|l|l|}
$6(20.0)$ \\
\end{tabular} & & \\
\hline $\mathrm{Mn}$ & Medium & $7(23.3)$ & $23(76.7)$ & 0.045 & $<0.001$ & $20(66.7)$ & $10(33.3)$ & 0.008 & 0.02 & $16(53.3)$ & $14(46.7)$ & 0.519 & 0.1 \\
\hline & High & \begin{tabular}{|l|}
$14(43.8)$ \\
\end{tabular} & $18(56.2)$ & & & $19(59.4)$ & $13(40.6)$ & & & $23(71.9)$ & 9 9(28.1) & & \\
\hline & Low & $21(70.0)$ & $9(30.0)$ & & & $27(90.0)$ & $3(10.0)$ & & & $24(80.0)$ & \begin{tabular}{|l}
$6(20.0)$ \\
\end{tabular} & & \\
\hline $\mathrm{Pb}$ & Medium & $12(38.7)$ & $19(61.3)$ & 0.001 & $\mid<0.001$ & $22(71.0)$ & $9(29.0)$ & 0.002 & 0.01 & $19(61.3)$ & $12(38.7)$ & 0.168 & 0.2 \\
\hline & High & $8(26.7)$ & $22(73.3)$ & & & $16(53.3)$ & $14(46.7)$ & & & \begin{tabular}{|l|}
$19(63.3)$ \\
\end{tabular} & $11(36.7)$ & & \\
\hline & Low & $22(73.3)$ & $8(26.7)$ & & & $<0.001$ & $3(10.0)$ & & & $25(83.3)$ & $5(16.7)$ & & \\
\hline $\mathrm{Tl}$ & Medium & $10(34.5)$ & $19(65.5)$ & 0.001 & $\mid<0.001$ & $<0.001$ & $7(24.1)$ & 0.001 & 0 & $18(62.1)$ & $11(37.9)$ & 0.057 & 0.1 \\
\hline & High & $10(30.3)$ & $23(69.7)$ & & & $<0.001$ & $16(48.5)$ & & & $20(60.6)$ & $13(39.4)$ & & \\
\hline & Low & & & & & $29(90.6)$ & $3(9.4)$ & & & $23(71.9)$ & $9(28.1)$ & & \\
\hline $\mathrm{Al}$ & \begin{tabular}{|l|} 
Medium \\
\end{tabular} & Not measured & & & & $20(71.4)$ & $8(28.6)$ & 0.001 & $<0.01$ & $18(64.3)$ & $10(35.7)$ & 0.789 & 0.8 \\
\hline & High & & & & & $17(53.1)$ & $15(46.9)$ & & & $22(68.8)$ & $10(31.2)$ & & \\
\hline & Low & & & & & $28(96.6)$ & $1(3.4)$ & & & $23(79.3)$ & $6(20.7)$ & & \\
\hline sb & Medium & Not measured & & & & $22(68.8)$ & $10(31.2)$ & $<0.001$ & $<0.01$ & $19(59.4)$ & $13(40.6)$ & 0.352 & 0.2 \\
\hline & High & & & & & $16(51.6)$ & $15(48.4)$ & & & $21(67.7)$ & $10(32.3)$ & & \\
\hline & Low & & & & & $30(93.8)$ & $2(6.2)$ & & & $26(81.2)$ & \begin{tabular}{|l}
$6(18.8)$ \\
\end{tabular} & & \\
\hline Co & Medium & Not measured & & & & $18(60.0)$ & $12(40.0)$ & 0.003 & $<0.01$ & $17(56.7)$ & $13(43.3)$ & 0.208 & 0.1 \\
\hline & High & & & & & $18(60.0)$ & $12(40.0)$ & & & $20(66.7)$ & $10(33.3)$ & & \\
\hline & Low & & & & & $26(89.7)$ & $3(10.3)$ & & & $21(72.4)$ & $8(27.6)$ & & \\
\hline $\mathrm{Cr}$ & Medium & Not measured & & & & $23(74.2)$ & $8(25.8)$ & 0.002 & 0.01 & $22(71.0)$ & $9(29.0)$ & 0.402 & 0.7 \\
\hline & High & & & & & $17(53.1)$ & $15(46.9)$ & & & $20(62.5)$ & $12(37.5)$ & & \\
\hline & Low & & & & & $24(85.7)$ & $4(14.3)$ & & & $22(78.6)$ & $5(21.4)$ & & \\
\hline Sn & Medium & Not measured & & & & $24(72.7)$ & $9(27.3)$ & 0.019 & 0.06 & $21(63.6)$ & $12(36.4)$ & 0.258 & 0.4 \\
\hline & High & & & & & $18(58.1)$ & $13(41.9)$ & & & $20(64.5)$ & $11(35.5)$ & & \\
\hline & Low & & & & & $26(89.7)$ & $3(10.3)$ & & & $23(79.3)$ & $6(20.7)$ & & \\
\hline $\mathrm{v}$ & Medium & Not measured & & & & $21(70.0)$ & $9(30.0)$ & 0.006 & 0.02 & $19(63.3)$ & $11(36.7)$ & 0.197 & 0.3 \\
\hline & High & & & & & $19(57.6)$ & $14(42.4)$ & & & $21(63.6)$ & $12(36.4)$ & & \\
\hline & Low & & & & & $19(70.4)$ & $8(29.6)$ & & & $24(88.9)$ & $3(11.1)$ & & \\
\hline в & Medium & Not measured & & & & $23(71.9)$ & 9 (28.1) & 0.842 & 0.98 & $20(62.5)$ & $12(37.5)$ & 0.23 & $<0.001$ \\
\hline & High & & & & & $24(72.7)$ & $9(27.3)$ & & & $19(57.6)$ & $14(48.3)$ & & \\
\hline
\end{tabular}

Table 3. Relation between heavy metal concentration and the presence of nosebleed, white lines on nails and chronic colic. $N$ number of children, $X^{2}$ chi-square test, $A l$ aluminium, $A s$ arsenic, $B$ boron, $C d$ cadmium, Co cobalt, $\mathrm{Cr}$ chromium, $\mathrm{Fe}$ iron, $\mathrm{Mn}$ magnesium, $\mathrm{Pb}$ lead, $\mathrm{Sb}$ antimony, $\mathrm{Sn}$ tin, $\mathrm{Tl}$ thallium, $V$ vanadium.

The exposure to heavy metal is chronic as children exposed to the open-pit mine continue to have high levels of heavy metals as reported in $2016^{23}$. The increased concentration of many heavy metals in hair root samples collected in 2018 as compared to that of 2016, and the presence of higher amount of heavy metals in hair tip than in hair root samples indicate an elevated diffusion of heavy metals in the environment from the expansion of mining activity in Peruvian Andes ${ }^{17}$. It should be noted that the Cerro mine was forced to build a wall in spring 2017 as a barrier to protect the inhabitants from heavy metal contamination, yet our findings reveal that the barrier is not a sufficient protective measure as high heavy metals concentrations were detected after the wall construction.

We showed a higher level of heavy metals in hair tip than in hair root samples of 2018. Hair tips are considered to be exposed for longer duration to heavy metals; between 12 and 28 months according to the speed of hair growth ${ }^{32}$.

The health effects of heavy metals depend on their concentration as well as on the co-exposure to other metals ${ }^{33}$. Therefore, although we showed that exposed children have high concentrations of most heavy metals and the latter is associated with several clinical symptoms, it was not possible to establish a clinical picture that characterizes each metal specifically. If the children had not presented high concentration of multiple heavy metals, it would have been easier to establish a relationship between the symptoms and a particular metal, since the health effects of each heavy metal is already known such as the case of lead (lead poisoning), mercury (Minamata disease) and arsenic (arsenicosis) ${ }^{15,34}$. It is also worthy to remember that long-term exposure to heavy metals is associated with the development of fatal diseases such as kidney failure, different types of cancer, and neuronal damage $e^{1,3,13-16}$. 


\begin{tabular}{|c|c|c|c|c|}
\hline Metal $(\mathrm{mg} / \mathrm{Kg})$ & Residence area & $\mathbf{N}$ & Average concentration $(\mathrm{mg} / \mathrm{kg})$ & \begin{tabular}{|l} 
T-student \\
p-value
\end{tabular} \\
\hline \multirow{2}{*}{$\mathrm{Al}$} & Carhuamayo & 16 & 22.3125 & \multirow{2}{*}{0.025} \\
\hline & Paragsha & 76 & 30.2171 & \\
\hline \multirow{2}{*}{$\mathrm{Sb}$} & Carhuamayo & 16 & 0.0498 & \multirow{2}{*}{$<0.001$} \\
\hline & Paragsha & 76 & 0.1156 & \\
\hline \multirow{2}{*}{ As } & Carhuamayo & 16 & 0.1762 & \multirow{2}{*}{$<0.001$} \\
\hline & Paragsha & 76 & 0.4676 & \\
\hline \multirow{2}{*}{$\mathrm{Cd}$} & Carhuamayo & 16 & 0.0416 & \multirow{2}{*}{0.001} \\
\hline & Paragsha & 76 & 0.0988 & \\
\hline \multirow{2}{*}{$\mathrm{Cr}$} & Carhuamayo & 16 & 0.3931 & \multirow{2}{*}{$<0.001$} \\
\hline & Paragsha & 76 & 0.8303 & \\
\hline \multirow{2}{*}{$\mathrm{Fe}$} & Carhuamayo & 16 & 29.8157 & \multirow{2}{*}{$<0.001$} \\
\hline & Paragsha & 76 & 55.1053 & \\
\hline \multirow{2}{*}{$\mathrm{Pb}$} & Carhuamayo & 16 & 0.8100 & \multirow{2}{*}{$<0.001$} \\
\hline & Paragsha & 76 & 4.6247 & \\
\hline \multirow{2}{*}{ Sn } & Carhuamayo & 16 & 0.1139 & \multirow{2}{*}{$<0.001$} \\
\hline & Paragsha & 76 & 41.9969 & \\
\hline \multirow{2}{*}{$\mathrm{Tl}$} & Carhuamayo & 16 & 0.0051 & \multirow{2}{*}{$<0.001$} \\
\hline & Paragsha & 76 & 0.192 & \\
\hline
\end{tabular}

Table 4. Association between area of residence and heavy metal concentration. Carhuamayo: region unexposed to the mine; Paragsha: region exposed to the mine. $N$ number of children.

\begin{tabular}{|c|c|c|c|c|}
\hline Clinical sign & $\begin{array}{l}\text { Unexposed region (Carhuamayo) } \\
\text { N (\%) }\end{array}$ & $\begin{array}{l}\text { Exposed region (Paragsha) } \\
\text { N (\%) }\end{array}$ & Odds ratio & $\begin{array}{l}\text { Odds ratio } \\
\text { p-value }\end{array}$ \\
\hline \multicolumn{5}{|c|}{ History of nosebleed } \\
\hline No & $14(87.5)$ & $29(37.2)$ & \multirow{2}{*}{15.40} & \multirow{2}{*}{$<0.001$} \\
\hline Yes & $2(12.5)$ & $49(62.8)$ & & \\
\hline \multicolumn{5}{|c|}{ White lines on nails } \\
\hline No & $16(100)$ & $51(65.4)$ & 12.10 & 0.001 \\
\hline Yes & $0(0.0)$ & $27(34.6)$ & & \\
\hline \multicolumn{5}{|l|}{ Chronic colic } \\
\hline No & $15(93.8)$ & $49(62.8)$ & 7.30 & 0.007 \\
\hline Yes & $1(6.2)$ & $29(37.2)$ & & \\
\hline \multicolumn{5}{|c|}{ Dermatologic alterations } \\
\hline No & $16(100)$ & $63(80.8)$ & 6.16 & 0.013 \\
\hline Yes & $0(0)$ & $15(19.2)$ & & \\
\hline \multicolumn{5}{|c|}{ Mood alterations } \\
\hline No & $16(100)$ & $61(78.2)$ & 7.07 & 0.008 \\
\hline Yes & $0(0)$ & $17(21.8)$ & & \\
\hline \multicolumn{5}{|l|}{ Constipation } \\
\hline No & $16(100)$ & $64(82.1)$ & 5.71 & 0.017 \\
\hline Yes & $0(0)$ & $14(17.9)$ & & \\
\hline \multicolumn{5}{|c|}{ Reduced visual field } \\
\hline No & $16(100)$ & $68(97.2)$ & 3.97 & 0.046 \\
\hline Yes & $0(0)$ & $10(12.8)$ & & \\
\hline \multicolumn{5}{|c|}{ Other clinical symptoms } \\
\hline No & $15(93.8)$ & $54(69.2)$ & 5.12 & 0.024 \\
\hline Yes & $1(6.2)$ & $24(30.8)$ & & \\
\hline
\end{tabular}

Table 5. Association between place of residence and manifestation of certain clinical signs. $N$ number of children, $X^{2}$ chi-square test. Dermatologic alterations include café-au-lait spots in flexor areas of the abdomen, back, chest or neck, calluses on palms of the hands, soles with thick and rough skin and calluses in areas without friction; other clinical symptoms encompassed bluish line on the gum, calluses in body areas without friction, calluses on palms and sole with thick and rough skin and inflamed conjunctiva. 
We reported the presence of a higher concentration of heavy metals in boys than in girls exposed to the mine which could be related to cultural habits (family role and playing outside) that would give rise to gender difference in exposure to environmental agents.

Our findings about the presence of higher concentration of heavy metals in children living in the region exposed to the mine than in those living in the unexposed region is in line with that of previous studies about the presence of high heavy metals concentration in blood of Cerro de Pasco children as well as the contamination of the water and soil of the region by heavy metals ${ }^{21,24,25}$.

Our study has several limitations. The sample size of the unexposed group was small. Due to the design of our study, ecologic study design, the estimate heavy metal concentrations are proxy and not individual based as the rely on the average concentration of those metals in the population. The estimated measures of association (odds ratio) therefore were crude, i.e., not adjusted for potentially confounding variables. Despite these limitations, we believe that our study help point out the hazardous effects of mining activities without protective measures on the environment and health.

\section{Conclusions}

The mining activities in Peru is a continuous threat to the environment and health of children living near the mine. They are associated with up to 15 folds increased risk of developing various health conditions. Actions should be taken to protect the environment and health.

\section{Data availability}

All relevant data are included within the paper. Data contain potentially identifying information and sensitive participants information. For all these reasons, the authors must not upload the dataset to a stable, public repository. However, the authors agree to make freely available any materials and data described in the publication upon reasonable request to joseignacio.munoz.barus@usc.es, principal investigator of this project and professor at University of Santiago de Compostela.

Received: 13 August 2021; Accepted: 10 November 2021

Published online: 23 November 2021

\section{References}

1. Al Osman, M., Yang, F. \& Massey, I. Y. Exposure routes and health effects of heavy metals on children. Biometals 32(4), 563-573. https://doi.org/10.1007/s10534-019-00193-5 (2019).

2. Jarup, L. Hazards of heavy metal contamination. Br. Med. Bull. 68, 167-182. https://doi.org/10.1093/bmb/ldg032 (2003).

3. Jaishankar, M., Tseten, T., Anbalagan, N., Mathew, B. B. \& Beeregowda, K. N. Toxicity, mechanism and health effects of some heavy metals. Interdiscip. Toxicol. 7(2), 60-72. https://doi.org/10.2478/intox-2014-0009 (2014).

4. Fashola, M. O., Ngole-Jeme, V. M. \& Babalola, O. O. Heavy metal pollution from gold mines: Environmental effects and bacterial strategies for resistance. Int. J. Environ. Res. Public Health. 13, 11. https://doi.org/10.3390/ijerph13111047 (2016).

5. EUROPOL. Environmental Crime. 2021. https://www.europol.europa.eu/crime-areas-and-trends/crime-areas/environmentalcrime. Accessed 01 June 2021

6. Panhwar, A. H., Tuzen, M., Hazer, B. \& Kazi, T. G. Solid phase microextraction method using a novel polystyrene oleic acid imidazole polymer in micropipette tip of syringe system for speciation and determination of antimony in environmental and food samples. Talanta 184, 115-121. https://doi.org/10.1016/j.talanta.2018.03.004 (2018).

7. Tuzen, M., Altunay, N., Hazer, B. \& Mogaddam, M. R. A. Synthesis of polystyrene-polyricinoleic acid copolymer containing silver nano particles for dispersive solid phase microextraction of molybdenum in water and food samples. Food Chem. 369, 130973. https://doi.org/10.1016/j.foodchem.2021.130973 (2022).

8. Tuzen, M., Sari, A. \& Saleh, T. Synthesis, characterization and evaluation of carbon nanofiber modified-polymer for ultra-removal of thorium ions from aquatic media. Chem. Eng. Res. Des. 163, 76-84. https://doi.org/10.1016/j.cherd.2020.08.021 (2020).

9. Tuzen, M., Saleh, T. \& Sari, A. Interfacial polymerization of trimesoyl chloride with melamine and palygorskite for efficient uranium ions ultra-removal. Chem. Eng. Res. Des. 159, 353-361. https://doi.org/10.1016/j.cherd.2020.04.034 (2020).

10. Saleh, T., Al-Ruwayshid, S. H., Sari, A. \& Tuzen, M. Synthesis of silica nanoparticles grafted with copolymer of acrylic acrylamide for ultra-removal of methylene blue from aquatic solutions. Eur. Polymer J. 130, 109698 (2020).

11. Jan, A. T. et al. Heavy metals and human health: Mechanistic insight into toxicity and counter defense system of antioxidants. Int. J. Mol. Sci. 16(12), 29592-29630. https://doi.org/10.3390/ijms161226183 (2015).

12. Shi, H., Shi, X. \& Liu, K. J. Oxidative mechanism of arsenic toxicity and carcinogenesis. Mol. Cell Biochem. 255(1-2), 67-78. https:// doi.org/10.1023/b:mcbi.0000007262.26044.e8 (2004).

13. Sall, M. L., Diaw, A. K. D., Gningue-Sall, D., Efremova Aaron, S. \& Aaron, J. J. Toxic heavy metals: Impact on the environment and human health, and treatment with conducting organic polymers, a review. Environ. Sci. Pollut. Res. Int. 27(24), 29927-29942. https://doi.org/10.1007/s11356-020-09354-3 (2020).

14. Londoño, L. F., Londoño, P. T. \& Muñoz, F. G. Los riesgos de los metales pesados en la salud humana y animal. Rev. Bio Agro 14(2), 145-153. https://doi.org/10.18684/BSAA(14)145-153 (2016).

15. Nordberg, G. Metales: Propiedades Químicas y Toxicidad. Madrid Mager I Enciclopedia de Salud y Seguridad en el Trabajo (2001).

16. Sharma, B., Singh, S. \& Siddiqi, N. J. Biomedical implications of heavy metals induced imbalances in redox systems. Biomed. Res. Int. 2014, 640754. https://doi.org/10.1155/2014/640754 (2014).

17. BBVA Research. Peru. Situation of the Mining Sector. 2019. https://www.bbvaresearch.com/wp-content/uploads/2019/03/Peru_ MiningSector.pdf. Accessed 01 June 2021.

18. The World Bank. Environmentally and Socially Sustainable Development Department. Wealth and Sustainability: The Environmental and Social Dimensions of the Mining Sector in Peru. Washington2005. https://documents.worldbank.org/pt/publication/ documents-reports/documentdetail/234531468776740743/main-report. Accessed 01 June 2021.

19. Source International. Cerro de Pasco, Peru. 2021. https://www.source-international.org/featured-cerro-de-pasco. Accessed 18 May 2021.

20. Quispe-Zuinga, M. R., Santos, F., Callo-Concha, D. \& Greve, K. Impact of heavy metals on community farming activities in the Central Peruvian Andes minerals. Minerals 9(10), 647. https://doi.org/10.3390/min9100647 (2019).

21. Source International. Análisis Ambiental de la Calidad de los Recursos Hídricos en la Zona Minera de Cerro de Pasco-Perú. 2018. https://www.source-international.org/. Accessed 18 May 2021. 
22. Source International. Condiciones de la Calidad Ambiental y Exposición a Metales Pesados en Cerro de Pasco-Perú. 2017. https:// www.source-international.org. Accessed 18 May 2021.

23. Source International. Informe Científico. Biomonitoreo de Metales en Niños y Niñas del Centro Poblado de Paragsha, Cerro de Pasco-Perú. 2017. https://www.source-international.org. Accessed 18 May 2021.

24. Bianchini, F. et al. Elemental contamination of an open-pit mining área in the Peruvian Andes. Int. J. Environ. Sci. Technol. 12, 1065-1074. https://doi.org/10.1007/s13762-013-0493-8 (2015).

25. Centro labor. Boletín 36: Análisis Participativo de la Calidad de los Suelos en Poblaciones Afectada por la Actividad Minera en Pasco. Lima, Color. C (2013).

26. van Geen, A., Bravo, C., Gil, V., Sherpa, S. \& Jack, D. Lead exposure from soil in Peruvian mining towns: A national assessment supported by two contrasting examples. Bull. World Health Organ. 90, 878-888. https://doi.org/10.2471/BLT.12.106419 (2012).

27. Amnesty International. Peru: New Evidence Confirms Health Crisis Due to Toxic Metals in Espinar. 2021. https://www.amnesty. org/en/latest/news/2021/05/peru-crisis-de-salud-metales-toxicos-espinar/. Accessed 01 June 2021.

28. United States Environmental Protection Agency (EPA) National Center for Environmental Assessment \& Integrated Risk Information System (IRIS). Chemical Assessment Summary. https://cfpub.epa.gov/ncea/iris/search/index.cfm. Accessed 13 August 2021.

29. Dajer, T. High in the Andes, A Mine Eats a 400-Year-Old City. 2015. https://www.nationalgeographic.com/history/article/151202Cerro-de-Pasco-Peru-Volcan-mine-eats-city-environment. Accessed 01 June 2021.

30. Jenkins, D. Toxic Trace Metals in Mammalian Hair and Nails. 1979. https://cfpub.epa.gov/si/si_public_record_Report.cfm?Lab= ORD\&dirEntryID=45357. Accessed 18 May 2021.

31. U.S. EPA. Method 6020B. Inductively Coupled Plasma-Mass Spectrometry. Washington, DC., 2014. Report No.: SW-846 Update V, Revision 2.

32. Pragst, F. \& Balikova, M. A. State of the art in hair analysis for detection of drug and alcohol abuse. Clin. Chim Acta. 370(1-2), 17-49. https://doi.org/10.1016/j.cca.2006.02.019 (2006).

33. Xarau, S.N. Toxicología Clínica: Bases Para el Diagnóstico y el Tratamiento de las Intoxicaciones en Servicios de Urgencias, Áreas de Vigilancia Intensiva y Unidades de Toxicologia (GEA Consultoría Editorial, S.L., 2019).

34. Ferrer, A. Intoxicación por metales. Anal. Sistema Sanitario Navarra 26(Suppl 1), 141-153 (2003).

\section{Acknowledgements}

This study is supported by a grant from Xunta de Galicia - Spain [Proxectos Plan Galego IDT (ED431C 2021/35)]. The funding source has not any role in the design of this study, data collection, analysis and interpretation, writing the manuscript or decision for publication.

\section{Author contributions}

X.F.: extraction of data from medical records and analytical results, debugging and development of the database. M.T.A.: preparation of the first draft. N.M.: investigation, data interpretation, and writing the original draft of the manuscript. F.C.-I.: methodology, formal analysis, and supervision. N.G.J.: physical examination and anamnesis. D.N.V.: funding acquisition, physical examination and anamnesis, and data interpretation. F.B.: data analytical results, funding acquisition. J.I.M.-B.: conceptualization, funding acquisition, data interpretation and supervision. All authors: Writing-review \& editing.

\section{Competing interests}

The authors declare no competing interests.

\section{Additional information}

Supplementary Information The online version contains supplementary material available at https://doi.org/ 10.1038/s41598-021-02163-9.

Correspondence and requests for materials should be addressed to N.M.

Reprints and permissions information is available at www.nature.com/reprints.

Publisher's note Springer Nature remains neutral with regard to jurisdictional claims in published maps and institutional affiliations.

(c) (i) Open Access This article is licensed under a Creative Commons Attribution 4.0 International License, which permits use, sharing, adaptation, distribution and reproduction in any medium or format, as long as you give appropriate credit to the original author(s) and the source, provide a link to the Creative Commons licence, and indicate if changes were made. The images or other third party material in this article are included in the article's Creative Commons licence, unless indicated otherwise in a credit line to the material. If material is not included in the article's Creative Commons licence and your intended use is not permitted by statutory regulation or exceeds the permitted use, you will need to obtain permission directly from the copyright holder. To view a copy of this licence, visit http://creativecommons.org/licenses/by/4.0/.

(c) The Author(s) 2021 